\title{
RIAD AZIZ KASSIS: THE BOOK OF PROVERBS \& ARABIC PROVERBIAL WORKS
}

\author{
Reviewed by P.J. Williams
}

It is rather surprising, given the quantity of secondary literature spawned by the comparison of biblical proverbs with those of other cultures, that so little has been written about the relationship between biblical proverbs and Arabic ones. Kassis's pioneering survey of extensive corpora of Arabic sayings that elucidate biblical material is therefore invaluable.

The first of the book's six chapters introduces the enterprise: comparison of biblical wisdom with that of Arabs has biblical precedent in 1 Kings 5:10, where Solomon's wisdom is described as

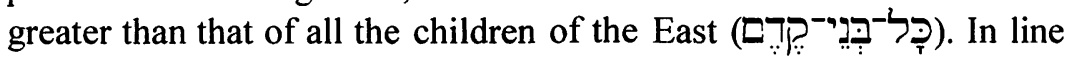
with this Kassis stresses the importance of Arabic comparative material, particularly from its pre-Islamic and early-Islamic phases.

Chapter two surveys the Solomonic wisdom tradition, and by standard arguments finds the attribution of biblical books, psalms and collections of proverbs to Solomon to be without historical basis. In considering the picture of Solomon in 1 Kings 3-11 Kassis thinks that differences between the MT and the LXX may indicate that this section was finalised later than the rest of the Deuteronomistic History, and that it

...cannot be regarded as reflecting a historical record. It reflects an obviously exaggerated account of the magnificence of Solomon and the types of his wisdom. Therefore, there is a highly probable reason for dating this tradition as post-exilic. (p. 47)

That said, "we do not rule out the possibility that Solomon as a king has uttered a few proverbs and wisdom sayings' (p. 47). This generally negative evaluation of the historicity of the picture of

1 (Leiden, Boston, Köln: Brill, 1999): a 'slightly revised edition' of a Ph.D. thesis (University of Nottingham, 1997) entitled 'A Critical and Comparative Study of the Book of Proverbs and Arabic Proverbial Wisdom-With special reference to social background and transmission-history'. 
Solomon as editor of proverbial literature provides the backdrop for a key comparison in Kassis's argument: that of Solomon and Luqmân.

Luqmân is a pre-Islamic figure who existed some time between King David and Muhammad. In Arabic literature he is characterised in various ways including as a prophet, a strong man and a wise man. This same Luqmân is probably the figure after whom the thirtyfirst Surah of the Quran is named. Once given divine approval in the Quran, it seems that Luqmân had more and more wise sayings attributed to him. Kassis's argument is that Luqmân and Solomon have resemblances such as that they are both designated in literature later than themselves as having divine approval and as being supremely wise.

It is our contention that the 'Luqmâns' of the Arabic tradition repeat a developing tradition of one probably historical person concerning whom legend and history were so mixed that a clear distinction between them has become difficult. In this Luqmân is comparable to Solomon. (p. 54)

However, one may question whether the similarities between the undatable sage and the datable head of state are so strong: the biblical tradition contains negative accounts of Solomon which do not find much parallel in Luqmân. Moreover, Kassis does little to explain how, if he only uttered a 'few proverbs and wisdom sayings', Solomon got a reputation for wisdom in the first place. This is less of a problem for Luqmân since we know so little of his circumstances.

Three chapters follow, each comparing a topic in the book of Proverbs-royalty, speech and silence, and wealth and povertywith its treatment in Arabic wisdom.

A positive aspect of the study of royal sayings in Arabic is that sometimes the historical setting of their creation can be discovered with more certainty than is the case for biblical ones. Kassis finds that Arabic proverbs critical of the ruler in some instances originate from rulers themselves (p. 76), both as a public relations exercise demonstrating their humility and as an attempt to show identification with their subjects. In fact brief proverbial sayings were an ideal means of spreading propaganda.

The chapter on speech and silence surveys the two literatures together under common headings, showing many similarities. Thus, both cultures see the tongue as potentially dangerous, even as a deadly weapon, and both talk of its need to be guarded. But differences also arise: whereas Proverbs connects the heart and the mouth, this connection is not made in Arabic sayings (p. 125). Moreover, at least two Arabic proverbs see positive aspects of lying 
(p. 144), while Proverbs 12:22 states that lying lips are an abomination to Yahweh. Arabic sayings on speech reflect various settings, which fortunately can be ascertained more easily than the settings of similar biblical statements. From this Kassis suggests that there is also a diversity of origin for the sayings in Proverbs. However, the similarities are not such that one need suppose influence on Arabic sayings from the book of Proverbs (p. 158).

While the literatures may draw the same conclusion on an issue of wealth or poverty (ch. 5), for instance that excessive sleep leads to poverty, the images used will be quite different, one set being drawn from bedouin society, and the other from a very agricultural one. There are also differences of content. Whereas Proverbs contrasts the wealthy and the poor, this contrast is entirely absent from classical Arabic sayings, which rather deal with these two groups separately (p. 220). In general, though, there is no unified social ethic behind either biblical or Arabic sayings. The explanation of this phenomenon is sought in diverse origin, and in the way, according to Kassis, the proverbs of the two cultures were worked over during the theological developments that occurred in them (p. 224).

The final chapter considers form-critical and traditio-historical aspects of the two sets of sayings. Kassis agrees with Westermann that biblical 'better than' (טוֹב מִן) sayings are 'popular proverbs', reflecting aspects of the life of common people, and argues that this is broadly true for Arabic 'better than' sayings too. However, whereas the Arabic sayings rarely occur in parallelism, the biblical ones often do.

The next form to be considered in the two literatures is that of numerical sayings. These exhibit similarities, though the step parallelism $(\mathrm{X} / / \mathrm{X}+1)$ of the Bible does not occur in the earliest Arabic sayings. That taken into account, perhaps the most striking similarity observed is between Proverbs 30:21-23 and the saying

Four [things] are not to be tolerated: A slave who has become a king, a rascal who is filled with food, a slave girl who received an inheritance, and an ugly woman who got married. (p. 236)

At each point the saying shows both similarities to and differences from the biblical one. Kassis concludes that the Arabic statement is most probably dependent on Proverbs (p. 238), though he does not speculate about the specific route of dependence.

It has been suggested that some two-line proverbs in the Bible could have originated as single-line proverbs since sometimes one half of a proverb occurs with different halves on different occasions 
(e.g. Pr. 10:6b and 10:11b). Kassis supports this view from Arabic, comparing for this purpose Proverbs 26:14 'a door turns on its hinges, and a sluggard on his bed' with the current proverb (from Najd, central Arabia) wiqafa 'albāb 'alā(y) șāyruh 'the door has got stuck on its hinges' (p. 259). He then suggests a new understanding for Proverbs 26:14 as referring to things that cannot be tolerated. This certainly seems like a long shot; 'door' and 'hinges' are the only common elements, and these are naturally co-occuring realia.

A satisfying area of formal contrast is that of sound. Kassis points out that assonance, rhyme and alliteration are common features of Arabic sayings. He could have made this point even more strongly. Whereas these features occur in Hebrew they do not seem to be so important there. However, what he fails to bring out is that the force of many Arabic proverbs actually depends on assonance or rhyme. Consider man jāla nāla 'he who walks around shall get success' (p. 183) or 'inna 'alḥusūma yūrit 'alḥusuūma 'diligence could cause exhaustion' (p. 184). These are short sayings built around the similar sound of two words. This finds little parallel in Hebrew, which has its own feature, namely parallelism, which is much less prominent in Arabic proverbs. I can posit several reasons for recurring structural differences between the two groups of sayings. (1) Arabic sayings are often considerably shorter than those in Proverbs. This does not allow for parallelism. (2) Whereas Proverbs is a single corpus the Arabic sayings are from more diverse sources. A filtering process to standardise form may have been active as sayings were collected into a corpus like Proverbs. (3) In Classical Arabic the case endings and the final short vowels on verbs give greater scope for developing rhyme than existed in Hebrew.

So, what of all this? How much light is really shed on biblical proverbs by Arabic ones? Certainly their evidence needs to be explored, and Kassis's book is the place from which to start. However, an issue that needs to be dealt with at greater length is that of possible influence from the Hebrew Bible on Arabic proverbs. Information from the Bible was available in the cradle of Islam, albeit in a restricted form, much having come via Aramaic. For comparative literature to be typologically comparative its independence is important. Kassis establishes independence somewhat as in the case of proverbs on speech and silence, but other scholars will still need more assurance of this and will look forward to illumination of this area from future research. 